\title{
Historia i współczesność programu CIP (Cataloguing in Publication)
}

\author{
Dorota Siwecka \\ Instytut Informacji Naukowej i Bibliotekoznawstwa \\ Uniwersytet Wroctawski
}

\begin{abstract}
Abstrakt
Cel/Teza: Celem artykułu jest podsumowanie 50-letniej działalności programu katalogowania w procesie wydawniczym (CIP) oraz określenie roli programu w rozwoju informacji bibliograficznej w drugim dziesięcioleciu XXI wieku.

Koncepcja/Metody badań: W pracy posłużono się metodą analizy piśmiennictwa. Analizie poddano zarówno artykuły dotyczące omawianej problematyki, jak i strony WWW instytucji odpowiedzialnych za realizację programu w poszczególnych krajach Europy, Stanach Zjednoczonych, Kanadzie i Australii. Wyniki i wnioski: Analiza rozwoju programu w badanych krajach pokazuje, że w większości przypadków nie rozwinął się on w pełni. W niektórych został zastąpiony inną formą informacji prospektywnej (np. w Niemczech). Najlepiej program rozwija się w Stanach Zjednoczonych jako narzędzie egzekwowania egzemplarza dla Biblioteki Kongresu.

Oryginalność/Wartość poznawcza: W literaturze pojawiają sią okresowo publikacje dotyczące programu CIP. Brakuje natomiast opracowań podsumowujących ostatnie 20-lecie funkcjonowania programu w kontekście rozwoju nowych technologii. W założeniu niniejszy artykuł ma wypełnić tę lukę.
\end{abstract}

\section{Słowa kluczowe}

Katalogowanie w trakcie procesu publikacji. Opis bibliograficzny. Opis CIP.

Otrzymany: 31 maja 2017. Zrecenzowany: 10 lipca 2017. Zaakceptowany: 11 września 2017.

\section{Wprowadzenie}

Najważniejsze organizacje i instytucje bibliotekarskie na świecie (IFLA, Biblioteka Kongresu, Biblioteka Brytyjska) od wielu lat usiłują wykreować swojego rodzaju model informacji bibliograficznej. Aby tego dokonać, wspólnie starają się ustalić zespół czynników tworzących informację bibliograficzną, które w głównej mierze wpływają na ukształtowanie bibliografii narodowych, a pośrednio również na inne (specjalne) spisy czy bazy bibliograficzne. W ciągu ostatnich dziesięcioleci, obok projektów ściśle związanych z bibliografią, na formowanie się tego modelu miały wpływ również inicjatywy, które przyczyniły się do tworzenia oraz rozpowszechniania bibliografii. Jedną z nich był program katalogowania dokumentów w trakcie procesu wydawniczego (ang. cataloguing in publication; CIP). Celem artykułu jest uaktualnienie informacji na temat programu katalogowania w trakcie procesu wydawniczego, który w Polsce nigdy nie stał się elementem szerszej współpracy między środowiskiem bibliotekarskimi i wydawniczym, a także wskazanie zmian, jakie nastąpiły w funkcji pełnionej przez CIP w ostatnich latach w krajach, w których program ten bardzo dobrze funkcjonuje. 
Na straty czasu spowodowane wielokrotnym opracowywaniem tego samego tytułu w różnych instytucjach zwrócił uwagę już w 1876 r. Justin Winsor, bibliotekarz z Harward College. Pod koniec XIX w. Henry B. Wheatley w pracy How to Catalogue a Library (Wheatley, 1889, 69) zaproponował, by każdy wydawca zamieszczał w swoich książkach kartę katalogową, sporządzoną przez rzetelną instytucję według ujednoliconych reguł. Zdawał sobie jednak sprawę, jak bardzo skomplikowane byłoby to wówczas przedsięwzięcie. Na początku lat 20. XX w. Biblioteka Kongresu rozpoczęła proces centralnego drukowania kart katalogowych dla swoich nabytków. System nie do końca jednak odpowiadał zapotrzebowaniu środowiska bibliotekarskiego. W praktyce sporządzanie opisu, drukowanie kart, a następnie rozsyłanie ich po kraju znacznie opóźniało proces dostarczania publikacji do rąk użytkownika końcowego. Dodatkową trudnością było także zorientowanie się w potrzebach konkretnych bibliotek i dostarczanie odpowiedniej liczby kart katalogowych danej książki, w zależności od liczby i rodzaju używanych w placówce katalogów. W latach 50. i 60. XX w. pojawiła się koncepcja katalogowania książek w trakcie procesu wydawniczego, tak by książka trafiająca do biblioteki posiadała już wydrukowany opis bibliograficzny (Kołacz, 2005, 65; Ramlau-Klekowska, 1990, 48). Realizacją tego pomysłu był międzynarodowy program Cataloguing in Publication ${ }^{1}$. Wynikiem takiego postępowania było umieszczenie w całym nakładzie książki opisu bibliograficznego, który, stworzony według ujednoliconych zasad, pozwalał również na szybkie i poprawne przejmowanie informacji bibliograficznych do innych celów informacyjnych, np. księgarskich.

W trakcie rozwoju programu nazywano tę formę katalogowania także „katalogowaniem u źródła” (ang. cataloguing in source), tzn. tam, gdzie książka powstaje (w wydawnictwie) lub „katalogowaniem w czasie druku” (ang. cataloguing in print), tzn. w okresie produkcji drukarskiej. Termin „katalogowanie w trakcie procesu publikacyjnego” (ang. cataloguing in publication) jest jednak terminem najbardziej ogólnym, ponieważ obejmuje również wydania niedrukowane, np. mikrofilmowe.

\section{Rozwój programu CIP}

Praktycznie katalogowanie w toku procesu publikacyjnego rozpoczęło się w Związku Radzieckim $^{2}$ w 1961 r. Do zamieszczenia opisu bibliograficznego w książce zobowiązany był wydawca, który miał współpracować z bibliotekami i izbami książki poszczególnych republik, tworząc opis zgodny z klasyfikacją biblioteczną i księgarską oraz odpowiednimi instrukcjami katalogowania. Rezultatem była drukowana w książce makieta karty katalogowej, którą można było skopiować w bibliotece. Zawierała ona opis bibliograficzny, symbol klasyfikacji rzeczowej oraz adnotację informującą o charakterze książki i jej treści (Daszkowski, 1975, 154; Ramlau-Klekowska, 1990, 51).

W Stanach Zjednoczonych pierwszą próbę wprowadzenia katalogowania w procesie publikacyjnym przeprowadzono w latach 1958-1959. „Katalogowaniem u źródła” (ang. cataloging in source) zajęła się wówczas Biblioteka Kongresu (BK). Koszty sporządzania

\footnotetext{
1 Pisownia amerykańska: cataloging in publication.

2 O specjalnych uchwałach i rozporządzeniach dotyczących CIP w Związku Radzieckim, a także o postanowieniach instrukcji wydanej w 1961 r. można przeczytać w artykułach: (Daszkowski, 1975, 153-154; Kołacz, 2005, 70; Ramlau-Klekowska, 1990, 51).
} 
opisów (zwłaszcza te leżące po stronie wydawców), czas poświęcony na przesyłanie pocztą makiet książek do BK i opisów bibliograficznych do wydawcy, a także błędy jakie pojawiły się już po wydrukowaniu dzieł (głównie dotyczące opisu fizycznego) oraz wątpliwości co do kierunku rozwoju tego programu, sprawiły, że eksperyment nie powiódł się i na 12 lat zarzucono tę praktykę. Głównym problemem okazało się zachęcenie wydawców do udziału w projekcie. W przeciwieństwie do bibliotek i bibliotekarzy, wydawcy w trakcie realizacji programu ponosili jedynie koszty, a nie widzieli w nim żadnych korzyści (Kołacz, 2005, 65).

Kolejną, tym razem udaną, próbę podjęto w 1971 r. Program nazwano wówczas „Cataloging in Publication”, by odróżnić go od poprzedniego nieudanego eksperymentu. Wydawcy tym razem docenili wartość gotowego, sporządzonego przez wyspecjalizowaną instytucję (tzw. centralę CIP) opisu, który mogli wykorzystać m.in. w swoich katalogach prospektywnych i bazach danych i chętnie przystąpili do kolejnej próby wdrożenia programu na terenie Stanów Zjednoczonych (Kołacz, 2005, 65; Ramlau-Klekowska, 1990, 49). Dodatkowym argumentem przemawiającym za udziałem w przedsięwzięciu był podkreślany przez biblioteki fakt obniżenia kosztów katalogowania w poszczególnych placówkach, a co za tym idzie wzrost środków na zakup nowości wydawniczych (Daszkowski, 1975, 158).

W sporządzanym opisie BK ograniczyła się do podstawowej informacji katalogowej tytułu dzieła, nazwy serii, numeru kontrolnego BK (Library of Congress Control Number LCCN) i numeru ISBN, a także hasła opisu bibliograficznego, uwag, symboli Klasyfikacji Dziesiętnej Deweya (KDD) i Klasyfikacji Biblioteki Kongresu (KBK), haseł przedmiotowych i haseł dodatkowych opisu - pominięto więc opis fizyczny i adres wydawniczy, w których wystąpiło poprzednio najwięcej błędów (Daszkowski, 1975, 159-160). Biblioteka Kongresu dostarczała wydawcy gotowy opis w ciągu 10 dni od uzyskania od niego odpowiednich materiałów ${ }^{3}$. Opis CIP drukowany jest współcześnie na stronie redakcyjnej książki oraz trafia do bazy BK, którą rozprowadza się raz w tygodniu w postaci elektronicznej (w formacie MARC) poprzez Cataloging Distribution Service (CDS) do dużych bibliotek, serwisów bibliograficznych i księgarzy na całym świecie. Dzięki temu opisy CIP służą też jako forma bibliograficznej informacji prospektywnej, która ułatwia politykę gromadzenia zbiorów oraz proces zamawiana książek w bibliotekach (LC, b.d.-a).

Podobne próby podjęto w latach 70. XX w. w Australii, Brazylii, Republice Federalnej Niemiec, Kanadzie i Wielkiej Brytanii. W Australii od 1974 r. program prowadzony jest przez dział biblioteki narodowej odpowiedzialny za tworzenie bibliografii narodowej, współpracujący z narodową agencją ISBN i narodowym ośrodkiem ISSN. Na podstawie danych dostarczanych przez wydawców centrala CIP w ciągu 10 dni roboczych sporządza opis katalogowy, a następnie dostarcza go do wydawcy. Informacje o publikacjach zamieszcza w narodowej bibliograficznej bazie danych - Australian National Bibliographic Database, która udostępnia swoje dane poprzez platformę Trove bibliotekom, księgarzom i innym użytkownikom na całym świecie. Dane te widoczne są również dla wyszukiwarek internetowych (np. Google) (NLA, b.d.).

W Wielkiej Brytanii opisy CIP tworzone były od 1975 r. przez Bibliotekę Brytyjską, która umieszczała je w bazie komputerowej w formacie zgodnym $\mathrm{z}$ formatem British National Bibliography (BNB) (wcześniej format UKMARC, obecnie MARC 21) jako zapowiedzi wydawnicze na dwa miesiące przed deklarowaną datą wydania. Od 1995 r. opisy CIP w Wielkiej

${ }^{3}$ Obecnie BK nie podaje, jak długo trzeba czekać na gotowy opis, zaleca natomiast, by przesyłać dane o wydawnictwach na pół roku przed ich opublikowaniem - (LC, b.d.-a). 
Brytanii tworzone są przez firmę prywatną Bibliographic Data Services Limited, która na zasadzie porozumienia z Biblioteką Brytyjską zbiera informacje od wydawców na 4 miesiące przed planowaną publikacją. Gotowe rekordy przekazywane są następnie do Biblioteki Brytyjskiej, gdzie trafiają do BNB z dopiskiem „Prepublication record” (British Library, 2014).

W Niemczech program CIP realizowany był w latach 1975-2002. Opisy (obejmujące piśmiennictwo niemieckojęzyczne z terenów Niemiec, Austrii i Szwajcarii) sporządzane w ramach programu publikowane były w serii „N” bieżącej bibliografii narodowej. Program zamknięto po przeprowadzeniu w 1999 r. ankiet wśród wydawców niemieckich, z których wynikało, że opisy CIP w kontekście rozwijających się technologii i dostępu do Internetu nie są już na tyle potrzebne, by zamieszczać je w książkach. Ponadto wydawcy zbyt późno przesyłali dane (często niepełne i błędne) do agencji CIP, co sprawiało, że opis CIP pojawiał się niemal równocześnie z pełnym opisem publikacji w bibliografii narodowej (Hammer, 1999, 11-13).

Oprócz modelu organizacyjnego centrali CIP zlokalizowanej w jednym ośrodku czy instytucji (np. w Australii, Holandii, Nigerii, Niemczech, USA i Wielkiej Brytanii) w niektórych krajach przyjęto model rozproszony. Ze względu na dużą powierzchnię kraju postąpiono tak w Kanadzie, organizując początkowo trzy ośrodki odpowiedzialne za tworzenie opisów CIP: publikacji anglojęzycznych w Toronto i Vancouverze, a francuskojęzycznych w Quebecu. W 2011 r. w Kanadzie funkcjonowały ośrodki w Ottawie oraz w Montrealu (dla wydawnictw francuskojęzycznych), a także oddzielne biura CIP dla publikacji rządowych zlokalizowane w Toronto, Winnipeg i Ottawie (LAC, b.d.). Nad całością przedsięwzięcia czuwała Biblioteka Narodowa Kanady, która zamieszczała wszystkie opisy CIP w bibliografii narodowej Canadiana. Od 2016 r. zrezygnowano z programu CIP dla publikacji urzędowych. Obecnie wydawnictwa anglojęzyczne opracowywane są przez Library and Archives Canada (LAC), a francuskojęzyczne przez Bibliothèque et Archives nationales du Québec w ciągu 15 dni roboczych od otrzymania materiałów od wydawcy (LAC, 2015). Dane dotyczące planowanych publikacji rejestrowane są w katalogu AMICUS, w innych katalogach bibliotecznych, a także w Books in Print (LAC, 2013).

W Polsce próbę zaprojektowania systemu CIP podjęto już w 1975 r. Początkowo zamierzano przejąć model funkcjonujący w ZSRR, ale różnice między wielkością i charakterem instytucji wydawniczych oraz pojawiające się wówczas wątpliwości co do realizacji pomysłu sprawiły, że ostatecznie zrezygnowano z wprowadzania programu. Dopiero na początku lat 80. XX w. stworzono propozycję dwóch modeli: scentralizowanego (z Instytutem Bibliograficznym BN jako główną instytucją) oraz zdecentralizowanego (zbliżonego do modelu radzieckiego). Przeprowadzone wówczas referendum wśród bibliotek wojewódzkich pokazało, że większość z nich opowiedziała się za pierwszym rozwiązaniem, ponieważ gwarantowało ono jednolitość i poprawność opisów. Wydawcy nie zostali wówczas poproszeni o przedstawienie własnej opinii. W 1985 r. przystąpiono do komputeryzacji Przewodnika Bibliograficznego, „który miał stanowić bazę warsztatową i personalną dla centrali CIP” (Kołacz, 2005, 73). Z uczestnictwa w programie skorzystała jedynie „Nasza Księgarnia”, przystępując do niego pod koniec 1986 r. (Ramlau-Klekowska, 1990, 58-59). W maju 1988 r. minister kultury i sztuki wydał oficjalne zarządzenie w sprawie drukowania opisów katalogowych i adnotacji w wydawnictwach zwartych (Zarzqddzenie..., 1988). Obowiązek sporządzania opisów CIP powierzono Instytutowi Bibliograficznemu BN (IB BN), który opracowywał bibliografię narodową. Programem objęto wszystkich wydawców (około 600) i wszystkie typy publikacji książkowych. Instytut Bibliograficzny zobowiązał 
się do tworzenia opisu w ciągu 48 godzin od momentu dostarczenia materiałów. Wydawcy sami musieli zadecydować, w którym momencie produkcji wysłać materiały do Biblioteki Narodowej. Mimo odpowiednich przepisów prawnych w 1989 r. IB BN opracowywał opisy książek jedynie dla 12 firm wydawniczych. Warto jednak odnotować, że w Polsce po raz pierwszy w skali światowej (z inicjatywy wrocławskiego Wydawnictwa Kartograficznego) wprowadzono opisy CIP do map (Kołacz, 2005, 74-75; Ramlau-Klekowska, 1990, 59-61).

W swoim artykule z 2005 r. Teresa Kołacz $(2005,76)$ napisała w odniesieniu do polskiej realizacji programu CIP:

\section{Szanse, że będzie lepiej, są raczej nikłe, bo powoli rolę programu CIP przejmuje Internet. Coraz więcej bibliotek ma do niego dostęp, a prezentowane tam katalogi wielu dużych bibliotek umożliwiają znalezienie poprawnego opisu bibliograficznego każdej nowej książki.}

Słaby rozwój programu CIP w Polsce ma swe źródło w braku zainteresowania nim wydawców (w badaniach z 2004 r. BN podała, że współpracują z 30 wydawnictwami (LC, 2005, 11)). Nie bez znaczenia jest tutaj znaczne rozdrobnienie rynku wydawniczego w Polsce po 1990 r., pogorszenie się sytuacji finansowej bibliotek, wynikające z kryzysu społeczno-ekonomicznego końca lat 80 . XX w. oraz brak do 2000 r. odpowiedniej infrastruktury telekomunikacyjnej i powszechnego dostępu do Internetu. Ponadto opisy CIP nie stanowią w Polsce podstawy do tworzenia bibliografii prospektywnych (opisów tych jest zresztą niewiele - ok. 350 rocznie (LC, 2005, 4)), nie są też dostępne z poziomu katalogu komputerowego dla użytkowników Biblioteki Narodowej, co z pewnością nie wpływa korzystnie na zainteresowanie programem wydawców.

\subsection{Badania rozwoju programu}

W 1975 r. sytuację programu w kilku państwach (USA, ZSRR, Brazylii i Australii ${ }^{4}$ ) przeanalizował i opisał L. R. Swindley (Swindley, 1975). W swoim raporcie omówił warunki, jakie powinny być spełnione w kraju, który planował wdrożyć scentralizowaną formę programu CIP. W 1982 r. zorganizowano międzynarodowe spotkanie ekspertów CIP w Ottawie. Biorący w nim udział bibliotekarze i wydawcy określili wówczas CIP „dziecięciem Kongresu Paryskiego" (Ramlau-Klekowska, 1990, 51)5. Rekomendacje tego spotkania (IFLA, 1986) stały się później podstawą do opracowania przewodnika CIP i poradnika jego realizacji: Guidelines for Cataloguing-in-Publication (Anderson, 1986).

W 1990 r. Hope Clement przedstawiła wyniki badań, z których wynikało, że 8 z 12 badanych bibliografii narodowych realizuje program CIP. Każda z tych narodowych agencji bibliograficznych przyznała, że wprowadzenie CIP przyspieszyło proces katalogowania bibliografii narodowych (Clement, 1990, 8). Osiem lat później, w 1998 r., Biblioteka Narodowa Kanady na zlecenie CDNL rozesłała ankiety dotyczące organizacji programu CIP na świecie. W odpowiedzi na ankietę 18 z 68 narodowych agencji bibliograficznych oświadczyło, że współpracują ze środowiskiem wydawców poprzez program CIP (NLC, 1998, 7).

\footnotetext{
4 Zamiary wprowadzenia CIP w RFN, Meksyku, Wielkiej Brytanii i Kanadzie autor omówił pobieżnie (Ramlau-Klekowska, 1990, 49).

${ }^{5}$ Już na wczesnym etapie wprowadzania różnych wersji katalogowania centralnego, okazało się, że nie jest ono możliwe bez uzgodnienia ujednoliconych w skali przynajmniej krajowej przepisów katalogowania. W trakcie Kongresu Paryskiego doszło do pierwszych ustaleń zmierzających do realizacji tej idei.
} 
Badania dotyczące rozwoju programu CIP prowadzi także Biblioteka Kongresu ${ }^{6}$. Wyniki badań przeprowadzonych w latach 2003-2004, opublikowane w 2005 r., wykazały, że programy CIP w poszczególnych krajach ${ }^{7}$ różniły się między sobą zarówno organizacją samego programu (forma zdecentralizowana lub scentralizowana), jak i rejestrowanymi formami dokumentów (książki, dokumenty muzyczne, mikroformy, wydawnictwa ciągłe itd.), formą dostarczania danych przez wydawców (wyłącznie w formie drukowanej, wyłącznie w formie elektronicznej, w obu postaciach, faksem albo osobiście), a także wymaganiami stawianymi wydawcom (nie w każdym kraju wydrukowanie opisu CIP na stronie redakcyjnej jest obowiązkowe i nie każda narodowa centrala bibliograficzna w zamian za sporządzenie opisu wymaga dostarczenia egzemplarza obowiązkowego) (LC, 2005).

W 2011 r. opisy CIP tworzone były m.in. w Australii, Czechach, Estonii, Kanadzie, na Litwie, w Nowej Zelandii, Polsce, Portugalii, Rosji, Słowenii, USA i Wielkiej Brytanii. Do jesieni 2011 r. na kształt programu CIP funkcjonowało także tworzenie opisów w Islandii, ale wyłącznie na potrzeby małych bibliotek, w których nie było odpowiednio przeszkolonych katalogerów ${ }^{8}$. Na Łotwie nie realizowano programu CIP, ale wydawcy, którzy chcieli otrzymać numer ISBN, musieli wysłać do narodowej centrali bibliograficznej odpowiednie metadane w postaci elektronicznej. Były one następnie zapisywane w bazie danych bibliografii narodowej, a po otrzymaniu egzemplarza obowiązkowego odpowiednio uzupełniane ${ }^{9}$.

W trakcie konferencji sekcji IFLA w Warszawie w 2012 r. „Bibliography in a Digital Age" (spotkanie satelickie towarzyszące kongresowi IFLA 2012) potwierdzono, że dane prospektywne, m.in. takie jak opisy CIP, nadal są wartościowe (IFLA WG, 2015).

\section{Zalety programu}

Program CIP w swoim założeniu miał znacznie obniżyć koszty katalogowania w poszczególnych bibliotekach. Ponadto opracowane w ten sposób wydawnictwa miały szybciej trafiać do rąk użytkowników. Opis CIP znajdujący się w książce miał być przydatny zwłaszcza w bibliotekach, w których brakuje dostępu do Internetu i które nie mogą ściągnąć gotowego opisu np. z bazy biblioteki narodowej albo w sytuacji, kiedy nie byłby możliwy dostęp do tych baz. Zapewne dlatego program szybko rozwinął się w okresie zmniejszania budżetów w bibliotekach i zwiększania się kosztów katalogowania w Stanach Zjednoczonych w latach 70. XX w. (Daszkowski, 1975, 160). Katalogowanie w trakcie procesu wydawniczego pozwalało również na sprawniejsze udostępnienie książki czytelnikowi - w niektórych bibliotekach dzięki opisom CIP można zarezerwować książkę jeszcze zanim trafi ona na biblioteczną półkę (Newlen, 1991, 42).

\footnotetext{
${ }^{6}$ Jeden z raportów ukazał się w 1986 r. (Mendenhall, 1982).

7 Program CIP funkcjonował w 25 krajach z 42, które odpowiedziały na ankietę.

${ }^{8}$ Informacje na podstawie ankiety przeprowadzonej przez autorkę w październiku 2011 r. na potrzeby rozprawy doktorskiej. W ankiecie pojawiły się 4 pytania dotyczące programu CIP: 1) Czy w kraju funkcjonuje program CIP? 2) Kto jest odpowiedzialny za tworzenie opisów CIP? 3) Czy opisy te są wykorzystywane przy sporządzaniu bieżącej bibliografii narodowej? 4) W jaki sposób wydawcy mogą wziąć udział w przedsięwzięciu oraz prośba o oszacowanie procentowego udziału wydawców. Ankietę rozesłano do 34 narodowych agencji bibliograficznych, z których 17 odpowiedziało na pytania autorki.

${ }^{9}$ Informacje na podstawie ankiety przeprowadzonej przez autorkę w październiku $2011 \mathrm{r}$.
} 
Podczas „Międzynarodowego Kongresu na temat Bibliografii Narodowych”, który odbył się w Paryżu w 1977 r. stwierdzono, że CIP jest pokrewną koncepcją w stosunku do zadań bieżącej bibliografii narodowej, a tworzenie opisów CIP uznano za rozszerzoną działalność narodowych central bibliograficznych. Zauważono wówczas również, że zbiór opisów CIP wydawany w niektórych krajach łącznie z bibliografią narodową, stanowi bibliograficzną informację prospektywną dla bibliotekarzy i użytkowników informacji (IFLA, 1979, 19). Przykładem może być ukazujące się w Czechach elektroniczne czasopismo O.K. Ohlášené Knihy (O.K., 2017), niemieckie Neuerscheinungsdienst, brytyjskie opisy publikowane w BNB. Dla bibliotek jest to źródło pomocne zwłaszcza przy kształtowaniu polityki gromadzenia zbiorów, a dla wydawców forma reklamy (udział wydawców w programie, który nie zapewnia dystrybucji opisów wydaje się być dla nich dużo mniej atrakcyjny).

Program CIP miał również, poprzez założenie współpracy środowiska wydawców z narodowymi centralami bibliograficznymi, zniwelować problem nieterminowego dostarczania egzemplarzy obowiązkowych (EO) do narodowych central bibliograficznych. W zamian za stworzenie opisu CIP wydawca powinien po opublikowaniu dzieła przesłać do agencji CIP EO w celu sprawdzenia poprawności danych i uzupełnienia opisu o informacje wcześniej niedostępne (takie jak paginacja, ilustracje, format itd.).

Współpraca bibliotekarzy i wydawców w trakcie realizacji programu pokazała również, że wiedza bibliotekarska nie jeden raz okazała się pomocna w pracy wydawniczej - m.in. przy kształtowaniu tytulatury dzieła (zwłaszcza dzieł wielotomowych, adaptacji, wznowień), ustalaniu kolejności wydań czy prawidłowym przydziale numerów ISBN. Ponadto wydawcy mogli wykorzystać gotowe opisy do własnej dokumentacji firmowej, reklamy i sporządzania katalogów wydawniczych (Ramlau-Klekowska, 1990, 59).

Mimo wymienionych zalet program katalogowania w procesie wydawniczym nie cieszy się popularnością, a dane zbierane w jego trakcie rzadko wykorzystuje się przy tworzeniu bieżących bibliografii narodowych (wyjątkami są Australia, Estonia, Litwa, Nowa Zelandia, Słowenia, Stany Zjednoczone czy Wielka Brytania). Najprawdopodobniej szybki rozwój nowych technologii i powszechny dostęp do Internetu i informacji bibliograficznej przyczyni się (podobnie, jak to miało miejsce w Niemczech czy Islandii) do stopniowego odejścia od programu również w innych krajach. Umocnienia pozycji programu CIP można się natomiast spodziewać w krajach, w których rozszerza się funkcje, jakie ma spełniać (np. w USA czy Kanadzie, gdzie służy m.in. do egzekwowania egzemplarzy dla bibliotek).

\section{Opis bibliograficzny CIP}

Według międzynarodowych zaleceń opis CIP powinien zawierać minimalną liczbę ustalonych elementów oznaczonych zgodnie z ISBD, m.in. międzynarodowy znormalizowany numer wydawnictwa (ISBN, ISSN) (Cybulski, 1978, 228). Ma to swoje odzwierciedlenie w elementach obowiązkowych, jakie wydawca musi podać przy wypełnianiu formularza (m.in. w USA, Australii, Wielkiej Brytanii).

W rekomendacjach ze spotkania w Ottawie w 1982 r. zamieszczono postanowienia dotyczące dwóch typów opisu CIP - zamieszczanych w wykazach prospektywnych i umieszczanych w książkach. W drugim przypadku, bardziej rygorystycznym, wymaga się przestrzegania międzynarodowych zasad opisu bibliograficznego i jednocześnie pomijania elementów, 
które nie są znane w momencie tworzenia opisu. Zalecano również, by opis CIP zawierał, oprócz opisu bibliograficznego, hasło opisu bibliograficznego i opis rzeczowy (IFLA, 1986).

W przypadku pierwszego rodzaju opisu (trafiającego do bazy) wymagana jest możliwa kompletność danych oraz jednoznaczna ich identyfikacja jako opisu CIP poprzez dodanie znormalizowanej formuły składającej się ze skrótu CIP oraz identyfikatora kraju albo nazwy jednostki odpowiedzialnej za tworzenie opisu, np. „CIP - Biblioteka Narodowa” dla polskich publikacji. Ponadto opis taki powinien zostać jak najszybciej zastąpiony prawidłowym opisem bibliograficznym wykonanym z autopsji w momencie opublikowania dzieła oraz powinien ukazać się w rejestrze każdej centrali CIP, jeśli dany wydawca bierze udział w więcej niż jednym programie. Rekomendacje nie mówiły jednak, jakie materiały tworzą podstawę do budowy opisu. Bazowano wówczas na odbitkach korektorskich, zwłaszcza stron tytułowych, redakcyjnych, kserokopiach projektów okładek i obwolut, makietach, odpisach danych z metryki drukarskiej itp. (Kołacz, 2005, 67-68; Ramlau-Klekowska, 1990, 54-56).

Współcześnie opisy CIP tworzone są na podstawie odbitek korektorskich publikacji (kopie strony tytułowej i strony redakcyjnej, reprodukcje niektórych lub wszystkich stron stanowiących preliminaria - przedmowa, spis treści, obwoluta) oraz specjalnych formularzy ${ }^{10}$, które muszą wypełnić wydawcy (przeważnie zamieszczane są na stronach internetowych central sporządzających opisy) i w których podawane są dodatkowe informacje dotyczące publikacji, takie jak: planowana data wydania, opis fizyczny i rzeczowy publikacji, szczegóły dotyczące związku publikacji z innymi wydaniami tego samego dzieła (Kołacz, 2005, 67). Zawartość formularzy zmienia się w czasie i dostosowywana jest do nowych technologicznych rozwiązań i zmian w przepisach katalogowania ${ }^{11}$.

Na podstawie dostarczanych informacji centrala tworzy skrócony opis katalogowy drukowany później w książce. Warto jednak zauważyć, że w tym punkcie program CIP nie do końca zgadzał się z założeniami programu „Universal Bibliographic Control”, który mówił o tym, że narodowe centrale bibliograficzne opracowują pełne autorytatywne opisy bibliograficzne na podstawie egzemplarza obowiązkowego. Opisy wykonywane w trakcie procesu publikacyjnego nie mogły więc zastąpić opisu bibliograficznego tworzonego na potrzeby narodowej rejestracji bibliograficznej. Mimo to, dzięki zastosowaniu zautomatyzowanych systemów już od lat 70. XX w., opis CIP stanowi gotowy fragment opisu bibliograficznego, który albo jest poprawiany i uzupełniany (np. w Australii), albo wymieniany na nowy pełny opis wraz z wpływem gotowego egzemplarza do centrali.

\section{CIP a rozwój nowych technologii - ECIP}

Ciągły rozwój nowych technologii w zakresie produkcji książki i form przekazywania informacji sprawia, że program CIP musi być na bieżąco dostosowywany do aktualnego

10 W 1985 r. sekcja katalogowania IFLA przedstawiła trzy wersje ujednoliconego formularza. Jednak ze względu na zbytnią szczegółowość informacji zrezygnowano z wprowadzenia go na skalę międzynarodową i określono, że o jego zawartości decydować ma centrala CIP (zlokalizowana najczęściej w ramach narodowej centrali bibliograficznej).

11 W 2014 r. BK przeprowadziła ankietę wśród wydawców. Jej wyniki przyczyniły się do zmian wprowadzonych w październiku 2015 r. w formularzu CIP oraz dostosowania przesyłanych informacji do nowych przepisów katalogowania RDA (LC, 2015). 
poziomu rozwoju technologicznego, tak by był nadal atrakcyjny dla środowisk bibliotekarskich, wydawniczych i księgarskich. W 1993 r. Biblioteka Kongresu przygotowała projekt pilotażowy elektronicznej wersji programu CIP o nazwie „Electronic CIP”. System wdrożono oficjalnie w 1999 r. Nowy program znacznie przyspieszył realizację procesu tworzenia opisów CIP, zmieniając formę przekazywania informacji od wydawcy do agencji bibliograficznej i z powrotem z mailowej na elektroniczną wymianę danych (Electronic Data Interchange - EDI). Ponadto wprowadzenie elektronicznej wersji programu i możliwości skopiowania i wklejenia informacji zmniejszyło liczbę pojawiających się wcześniej błędów literowych, jakie popełniano podczas ręcznego przepisywania zawartości opisu CIP (McCroskey \& Turvey, 2004, 39).

W 2007 r. BK na dobre zrezygnowała z tradycyjnej (papierowej) formy nadsyłania przez wydawców materiałów do tworzenia opisów CIP. Wydawcy przesyłają obecnie niezbędne informacje poprzez specjalny formularz znajdujący się na stronie WWW Biblioteki Kongresu oraz pełny tekst dzieła drogą elektroniczną. BK tworzy opis CIP i przesyła go wydawcy pocztą elektroniczną. Wersję tradycyjną programu utrzymano jedynie dla książek wydanych w innym języku niż angielski, książek, w których na stronie tytułowej pojawiają się znaki diakrytyczne języków innych niż zachodnioeuropejskie oraz książek, na których zawartość składają się głównie obrazy, tabele, wykresy, formuły matematyczne lub chemiczne itp. (z wyjątkiem książek dla dzieci) (LC, 2006).

\section{Alternatywa dla programu CIP}

Ograniczenia, jakie narzuciła BK w stosunku do przyjmowania zgłoszeń do programu ECIP zaowocowały nowymi przedsięwzięciami w amerykańskim środowisku wydawców, bibliotekarzy i pracowników informacji. Także w środowisku europejskim w ciągu ostatniego półwiecza pojawiły się inicjatywy dające możliwość kształtowania bibliograficznej informacji prospektywnej.

\subsection{EPCN (Electronic Preassigned Control Number)}

Wydawcom, którzy nie są w stanie skorzystać z elektronicznej wersji programu ECIP, a także tym, którzy nie spełniają warunków uczestnictwa w programie CIP w Stanach Zjednoczonych ${ }^{12}$, Biblioteka Kongresu zaproponowała alternatywną formę: program EPCN - Electronic Preassigned Control Number (elektronicznie nadawany numer kontrolny). W $2010 \mathrm{r}$. liczba wydawców biorących udział w tym programie (47 945) prawie dziesięciokrotnie przewyższała liczbę uczestników programu CIP (5008) (Debus-López, 2011).

PCN, czyli Preassign Control Number jest programem, który pozwala na przypisanie każdemu dziełu (jeszcze nieopublikowanemu przez wydawcę) specjalnego numeru kontrolnego BK (LCCN), który informuje użytkowników, że BK najprawdopodobniej nabędzie tę książkę. Do każdego wydawnictwa tworzony jest również opis bibliograficzny - w przeciwieństwie

${ }^{12}$ Do programu CIP w USA przystąpić mogą tylko wydawcy, którzy opublikowali minimum trzy dzieła różnych autorów. Ponadto do programu nie kwalifikują się publikacje wydawane nakładem autora oraz publikowane na życzenie - (LC, b.d.-a). 
jednak do programu CIP opisy te nie są rozprowadzane w postaci elektronicznej ani drukowane w książkach. Ponadto wydawca nie może brać udziału w obu przedsięwzięciach jednocześnie, ponieważ programy wzajemnie się wykluczają. Warto zauważyć, że wydawca umieszczając w książce jedynie numer kontrolny BK, znacznie ułatwia procesy związane z katalogowaniem w bibliotekach i księgarniach. Numer LCCN jest bowiem wykorzystywany przez biblioteki amerykańskie do wyszukiwania rekordów bibliograficznych w bazach danych i zamawiania kart katalogowych w BK lub u innych komercyjnych dostawców (LC, b.d.-b).

\subsection{P-CIP (Publishers Cataloging in Publication)}

Ponieważ w Stanach Zjednoczonych program CIP skierowany jest wyłącznie do wydawców, którzy rozprowadzają swoje publikacje na szeroką skalę, powstał projekt utworzenia podobnego programu dla publikacji ukazujących się w niskich nakładach.

W odróżnieniu od opisu CIP, który przygotowywany jest zawsze przez Bibliotekę Kongresu, opisy P-CIP sporządzają sami wydawcy, ich agenci (m.in. Quality Books Inc., Five Rainbows - Services for Authors \& Publishers) lub wyspecjalizowane firmy (np. Cassidy Cataloguing Services Inc., The Donohue Group, Inc.). Za wykonanie takiego opisu firmy te pobierają jednak opłatę. Ponadto do stworzenia opisu wymagany jest zawsze numer uzyskany w ramach PCN. Każdy opis P-CIP przekazywany jest do katalogu amerykańskiego OCLC WorldCat, z którego bibliotekarze mogą pobrać gotowy opis w formacie MARC.

\subsection{BIBLINK}

W połowie lat 90. XX w. z inicjatywy Unii Europejskiej powołano program BIBLINK, którego przedmiotem były publikacje elektroniczne, a głównym zadaniem miało być zapewnienie przepływu informacji pomiędzy narodowymi agencjami bibliograficznymi a wydawcami i użytkownikami. Wydawcy mieli za zadanie wprowadzić do systemu podstawowe dane, które następnie przesyłano do agencji bibliograficznych, gdzie były uzupełniane o dodatkowe informacje (m.in. hasła rzeczowe). Zmodyfikowane informacje miały wracać do wydawców, którzy mogli kodować je w wydawanych przez siebie publikacjach elektronicznych. Projekt zakładał wykorzystanie różnego rodzaju składni, m.in. HTML, SGML, UNIMARC i formatów narodowych MARC, tak by możliwa była wymiana informacji między wszystkimi uczestnikami programu. Po przeprowadzeniu wersji pilotażowej projektu, zamknięto go w lutym 2000 r. (Patel \& Clayphan, b.d.; Smith, 2001, 59).

\subsection{Neuerscheinungsdienst}

Biblioteka Niemiecka wprowadziła w 2003 r. darmowy serwis „Informacja o nowościach” („Neuerscheinungsdienst”), który zastąpił zamknięty w 2002 r. program CIP (Rinn, 2004, 47-51). Nowy serwis nie stanowi już członu bibliografii narodowej, ale opisy w nim zamieszczane uzupełniane są o symbole KDD stosowane również w bibliografii bieżącej (DNB, 2016). Dane o książkach pochodzą z katalogu „Verzeichnis Lieferbarer Bücher” (VLB) (niemiecki odpowiednik „Books in Print”), do którego wydawcy zgłaszają nowe tytuły za pośrednictwem Internetu, z wykorzystaniem formatu ONIX lub w wersji papierowej. Dane 
te są następnie w ciągu dwóch dni przekazywane do Niemieckiej Biblioteki Narodowej, która porządkuje je według treści zgodnie z KDD i publikuje je w kilku wersjach: jako tygodnik online w formacie PDF, za pomocą interfejsów OAI (Open Archives Initiative) i SRU (Search / Retrieve via URL), a także jako dane surowe (DNB, 2017).

\title{
7. Perspektywy rozwoju programu CIP
}

Już w międzynarodowych rekomendacjach z 1986 r. poruszono kwestię wątpliwej przyszłości programu, zwracając uwagę, że

\begin{abstract}
stałemu wzrostowi liczby publikowanych tytułów nie będzie zapewne towarzyszył proporcjonalny wzrost możliwości ich zakupu i gromadzenia w bibliotekach (...) zapotrzebowanie na wielokrotne opracowywanie tego samego tytułu w wielu bibliotekach może się zmniejszać, natomiast popyt na terminową i sprawną informację będzie rósł. Stąd przewidywane dalsze przesuwanie się punktu ciężkości ze znaczenia opisu umieszczonego w książce na opis wchodzący szybko do obiegu informacji, zwłaszcza wspomaganej techniką informatyczną (Ramlau-Klekowska, 1990, 55).
\end{abstract}

Przewidywania te potwierdziły się w przypadku niektórych krajów (np. Niemiec).

Współcześnie wiele ośrodków tworzących opisy CIP wypracowało własne rozwiązania dotyczące stopnia kompletności opisów, formy ich wykorzystywania w bibliografiach narodowych, a także sposoby kontrolowania za pomocą programu dopływu egzemplarza obowiązkowego od współpracujących wydawców. W rozwiązaniu tego ostatniego problemu w Stanach Zjednoczonych pomóc ma nowy proces, zapoczątkowany w BK w lutym 2010 r. zautomatyzowany proces dopominania się przez e-mail o książki, jakie wydawcy są zobowiązani przekazać BK. Wydawca będzie otrzymywał informację o zaległościach raz w miesiącu, a czas na odesłanie egzemplarza do BK będzie wynosił 90 dni. Nieprzesłanie egzemplarza z wyznaczonym terminie ma skutkować wykluczeniem wydawcy z programu (LC, b.d.-a).

W kontekście rozwoju nowych technologii i tworzenia nowego typu zasobów - e-booków, publikacji hybrydowych (posiadających komponenty tradycyjne i cyfrowe) - pojawiają się też pytania o kierunek dalszego rozwoju programu CIP oraz o sposób usprawnienia i ułatwienia przepływu danych między wydawcami a BK i innymi partnerami. Biblioteka Kongresu w raporcie opracowanym w 2009 r. przedstawiła zalecenie dotyczące wyeliminowania dublowania opisów $\mathrm{m}$. in. poprzez usprawnienie wymiany danych i pełną automatyzację programu CIP (LC, 2008, 15). W celu realizacji tego zamierzenia BK w czerwcu 2009 r. rozpoczęła pilotażowy projekt konwersji danych dostarczanych przez wydawców w formacie ONIX do programu ECIP. Dane konwertowane są do formatu MARC z zachowaniem zawartości takich elementów jak „spis treści” i „streszczenie”, występujących w formacie ONIX (LC, b.d.-a).

\section{Zakończenie}

Na podstawie danych wskazanych w artykule można stwierdzić, że informacja prospektywna publikowana jest tylko w niektórych krajach (USA, Wielka Brytania, Niemcy). W dobie nowoczesnych technologii, kiedy opisy publikacji trafiają do bibliografii narodowych dostępnych online w ciągu kilku dni od daty wydania, informacja ta wydaje się być zbędna 
dla bibliotekarzy jako źródło autorytatywnego opisu. Pozostaje jednak istotnym źródłem wpływającym na kształtowanie polityki gromadzenia zbiorów (planowania zakupów).

Opisy CIP zamieszczane na odwrocie strony tytułowej, mogą być ponadto wykorzystywane przez czytelników do spisywania podstawowych, a co najważniejsze - autorytatywnych danych o publikacji, którą właśnie przeglądają. Informacje te mogą wykorzystać m.in. przy tworzeniu przypisów czy bibliografii załącznikowych, katalogowaniu własnego księgozbioru, korekcie informacji zaczerpniętych z różnych źródeł m.in. do menedżerów bibliografii.

Nie można też nie zauważyć problemu egzekwowania EO w wielu krajach na świecie. Zapewne stąd zrodził się pomysł na wykorzystanie programu do monitowania o przesyłanie egzemplarza do $\mathrm{BK}^{13}$.

Nie ulega jednak wątpliwości, że przedsięwzięcia typu CIP miały największą szansę rozwoju w krajach, w których wysoko ceni się informację bibliograficzną, zwłaszcza w środowisku wydawców. Dodatkowym atutem jest zapewne ukazywanie się informacji prospektywnej. W Polsce co prawda funkcjonuje program CIP, ale opisy tworzone w jego ramach nie są udostępniane publicznie.

Śledząc historię rozwoju programu, zauważyć można, że ogromne znaczenie miała dla niego rewolucja technologiczna, jaka rozpoczęła się w połowie ubiegłego wieku. Pojawienie się elektronicznych formatów zapisu danych, nowoczesnych nośników informacji oraz zautomatyzowanie procesów w ośrodkach informacyjnych, bibliotekarskich, a także wydawniczych i księgarskich, sprzyjało nawiązywaniu współpracy między tymi środowiskami m.in. w zakresie realizacji programu CIP.

Od momentu powstania opisywanych inicjatyw nastąpiły też zmiany w obrębie funkcji opisu CIP - od ułatwiającego prace katalogowe w bibliotekach, poprzez podkreślenie funkcji informacji prospektywnej w środowisku bibliotek, księgarzy i użytkowników, po ostatni kierunek - testowany przez Bibliotekę Kongresu - wykorzystania programu do kontroli wpływu egzemplarza obowiązkowego. Zmiany te sprawiają, że obawy, jakie pojawiają się od lat 80 . XX w., związane $\mathrm{z}$ funkcjonowaniem programu w kontekście nowych technologii (m.in. powstaniem formatu ONIX) oraz dużej aktualności bieżących bibliografii narodowych, a tym samym z zanikiem zainteresowania tego typu informacją, okazują się być, przynajmniej w niektórych krajach, na razie niepotrzebne.

\section{Bibliografia}

Anderson, D. (1986). Guidelines for Cataloguing-in-Publication. Paris: IFLA.

British Library (2014). The Cataloguing-in-Publication Programme [online]. The British Library, [29.05.2017], http://www.bl.uk/bibliographic/natbib.html

Clement, H. E. A. (1990). National bibliographic agencies cataloguing survey. International Cataloguing and Bibliographic Control, 19(1), 6-10.

Cybulski, R. (1978). Międzynarodowy Kongres nt. Bibliografii Narodowych. Paryż, 12-15 września 1977 r. Przeglad Biblioteczny, 46(2), 223-230.

Daszkowski, Z. (1975). Katalogowanie książek w toku procesu publikacyjnego (na podstawie doświadczeń radzieckich i amerykańskich). Przeglad Biblioteczny, 43(2), 149-161.

${ }^{13}$ Należy też pamiętać, że problem egzekwowania EO wiąże się również z liczbą egzemplarzy, jaką należy przesłać uprawnionym placówkom (w Polsce 17 egzemplarzy jeśli nakład przekracza 100 egzemplarzy, 2 jeśli nakład jest mniejszy niż 100 egzemplarzy), co dla wielu wydawców stanowi spory wydatek. 
Debus-López, K. (2011). CIP Advisory Group Meeting. In: ALA 2011 Summer Conference [online]. New Orleans, [13.02.2017], http://www.loc.gov/publish/cip/cag

DNB (2016). Neuerscheinungsdienst [online]. Deutsche Nationalbibliothek, [13.02.2017], http://www. dnb.de/DE/Service/DigitaleDienste/ND/nd_node.html

DNB (2017). Neuerscheinungsdienst - Meldeverfahren [online]. Deutsche Nationalbibliothek, [04.09.2017], http://www.dnb.de/DE/Erwerbung/Meldeverfahren/meldeverfahren_node.html

Hammer, N. (1999). CIP-Eindruck in Verlagspublikationen. Dialog mit Bibliotheken, 11(3), 11-13.

IFLA (1979). IFLA International Office for UBC, Guidelines for the national bibliographic agency and the national bibliography. Paris: UNESCO.

IFLA (1986). Recommended standards for Cataloguing-in-Publication : the CIP data sheet and the CIP record in the book. London: IFLA International Programme for UBC.

IFLA WG (2015). Best Practice for National Bibliographic Agencies in a Digital Age [online]. IFLA Working Group on Guidelines for National Bibliographies [24.04.2017], https://www.ifla.org/ node/7858

Kołacz, T. (2005). Z historii programu CIP - Cataloguing in Publication. Zagadnienia Informacji Naukowej, 1(85), 64-80.

LAC (2013). Scope and coverage [online]. Library and Archives Canada, [29.05.2017], http://www. bac-lac.gc.ca/eng/services/cip/Pages/scope-coverage.aspx

LAC (2015). Frequently asked questions [online]. Library and Archives Canada, [25.05.2017], http:// www.bac-lac.gc.ca/eng/services/cip/Pages/faq.aspx

LAC (b.d.). List of CIP Agents for Canadian Publishers [online]. Library and Archives Canada [22.02.2017], http://www.collectionscanada.gc.ca/cip/041003-4000-e.html\#national_office

LC (2005). Survey of CIP Programs Report [online]. Library of Congress, [24.04.2017], www.loc.gov/ catdir/cipsurvey/IFLA_CIP_Survey_Report.pdf

LC (2006). ECIP Replaces Conventional CIP Program [online]. Library of Congress, [24.04.2017], http://cip.loc.gov/endofpaperCIP.html

LC (2008). On the record: report of The Library of Congress Working Group on the Future of Bibliographic Control [online]. Library of Congress. [13.02.2017], http://www.loc.gov/bibliographic-future/ news/lcwg-ontherecord-jan08-final.pdf

LC (2015). CIP Data: Cataloging in Publication Program - Publishers [online]. Library of Congress, [25.05.2017], https://www.loc.gov/publish/cip/techinfo/

LC (b.d.-a). Cataloging in Publication Program [online]. Library of Congress, [24.04.2017], http:// www.loc.gov/publish/cip/

LC (b.d.-b). Preassigned Control Number Program [online]. Library of Congress, [24.04.2017], https:// www.loc.gov/publish/pcn/

McCroskey, M., \& Turvey, M. (2004). Processing new CIP materials at the Library of Congress. Knowledge Quest, 32(3), 38-39.

Mendenhall, K. (1982). A survey of the cataloging in publication program. Final report. Washington, D.C.: Library of Congress.

NLA (b.d.). CiP user guide [online]. National Library of Australia, [07.03.2012], http://www.nla.gov. $\mathrm{au} / \mathrm{cip} /$ user-guide

NLC (1998). Comparative study of the role of national bibliographic agencies in achieving bibliographic control of their national publishing output. Final report on stage two prepared for CDNL. National Library of Canada.

Newlen, R. R. (1991). Read the fine print. The power of CIP. Library Journal, 116(12), 38-42.

O.K. (2017). O.K. Ohlášené knihy [online]. Praha: Národní knihovna České republiky. [29.05.2017], http://aleph.nkp.cz/web/ok.htm

Patel, M., \& Clayphan R. (b.d.). Project BIBLINK: Linking Publishers and National Bibliographic Agencies [online], [24.04.2017], http://www.ukoln.ac.uk/metadata/publications/biblink/proj-biblink.html 
Ramlau-Klekowska, K. (1990). Program „Cataloguing in Publication” w Polsce i na świecie. Katalogowanie książki w trakcie procesu wydawniczego. Editor, (3), 47-61.

Rinn, R. (2004). Der Neuerscheinungsdienst der Deutschen Bibliothek. Dialog mit Bibliotheken, $16(2), 47-51$.

Smith, R. (2001). Distribution and exchange. In: ICNBS Copenhagen 25-27 November 1998. Proceedings of International Conference on National Bibliographic Services. Copenhagen: The Royal Library, 53-60.

Swindley, L. R. (1975). Cataloguing in Publication: An International Survey. Paris: UNESCO.

Wheatley, H.B. (1889). How to Catalogue a Library. 2nd ed. London: Elliot Stock.

Zarządzenie nr 9 Ministra Kultury i Sztuki z dnia 16 maja 1988 r. w sprawie drukowania opisu katalogowego oraz adnotacji w wydawnictwach zwartych. (1988). Dziennik Urzędowy Ministerstwa Kultury i Sztuki, 4 (poz. 15).

\title{
The History and Today of Cataloging in Publication (CIP)Program
}

\begin{abstract}
Purpose/Thesis: The purpose of this article is to summarize the 50-year activity of the cataloging in publication (CIP) program and to define the role of the program in the development of bibliographic information in the second decade of the 21st century.

Approach/Methods: The literature analysis method was used. The analysis covered articles on the subject being discussed and the web sites of institutions responsible for the implementation of the program in Europe, the United States, Canada, and Australia.

Results and conclusions: The analysis of the program development in the surveyed countries shows that in most cases it has not been fully developed. In some countries it has been replaced by another form of prospective information (e.g. in Germany). The program is most advanced in the United States as a tool to enforce a copy for the Library of Congress.

Originality/Value: The literature shows some publications on CIP issues. However, there are not any reports compiling the last 20 years of the program in the context of the development of new technologies. This article is intended to fill a gap on the topic.
\end{abstract}

\section{Keywords}

Bibliographic description. Cataloging in Publication. CIP description

Dr DOROTA SIWECKA jest absolwentka Instytutu Informacji Naukowej i Bibliotekoznawstwa Uniwersytetu Wroctawskiego. W 2013 r. uzyskata stopień naukowy doktora w zakresie bibliologii i informatologii oraz kwalifikacje zawodowe bibliotekarza dyplomowanego. Obecnie pracuje jako wykładowca w IINiB UWr. Jej najważniejsze publikacje to m.in. Prace IFLA nad międzynarodowymi przepisami katalogowania. Przeglad Biblioteczny 2012, 319-336 oraz uhonorowana Nagroda im. A. Eysakowskiego SBP monografia Światowy model informacji bibliograficznej. Programy i projekty (1950-2010. Warszawa: Wydaw. SBP, 2015.

Kontakt $z$ autorka:

dorota.siwecka@uwr.edu.pl

Instytut Informacji Naukowej i Bibliotekoznawstwa

Uniwersytet Wroctawski

pl. Uniwersytecki 9/13

50-137 Wroctaw 